\title{
The Growth Study of Vero Cells in Different Type of Microcarrier
}

\author{
Yusilawati Ahmad Nor ${ }^{1}$, Nurul Hafizah Sulong', Maizirwan Mel ${ }^{1}$, Hamzah Mohd Salleh², Iis Sopyan ${ }^{3}$ \\ ${ }^{1}$ Bioprocess and Molecular Engineering Research Unit; ${ }^{2}$ Halal Industry Research Centre; ${ }^{3}$ Biomedical Engineering Research Group, \\ International Islamic University Malaysia, Kuala Lumpur. \\ Email: maizirwan@iiu.edu.my
}

Received June $10^{\text {th }}, 2010$; revised October $4^{\text {th }}, 2010$; accepted October $5^{\text {th }}, 2010$.

\begin{abstract}
The fact of microcarrier (MC) culture introduces new possibilities and makes possible the practical high-yield culture of anchorage-dependent cells has generated a considerable focus in this study. The objective of this research was to study the comparison of Vero cell growth on different types of commercial microcarriers; Cytodex-1, Cytodex-3, Hillex ${ }^{\circledR}$ II and Plastic Plus in spinner vessel and two liters bioreactor cultured for 96 hours. Biological performance of the microcarrier in RPMI media showed the preference of Vero cell grew on Cytodex 3 microcarriers with highest maximum viable cell number $\left(2.4 \times 10^{5}\right.$ cells $\left./ \mathrm{ml}\right)$ followed by Cytodex 1, Hillex and Plustic Plus. Vero cell on Cytodex-3 data in spinner flask was compared in bioreactor and result showed higher viable cell number in biorector. Thus, this dextran-crosslink gelatin microcarrier (Cytodex 3) provided the best surface for cell attachment and fast proliferation. At the end of this cell growth improvement will be used for virus transfection producing a vaccine in bioreactor.
\end{abstract}

Keywords: Cytodex 3, Microcarrier, Spinner Flask, Vero Cells, Vaccines

\section{Introduction}

Vero cell line was derived from the kidney of a normal, adult, African green monkey (Cercopithecus) [1]. Vero cells have been extensively used for producing viral vaccines [2-4] and for evaluating the performance of animal cell in bioreactors with modified condition [5]. This cell line also has been used extensively for virus replication studies and plaque assays [1]. Moreover, Vero cells do not disturb human health when used as substrate for biological product since they are free from oncogenic property $[2,6]$. However, Vero cells are anchorage dependent cells which required solid substrate to attach and grow. Thus, Vero cells can be used in microcarrier and suspension cultures for large scale production in bioreactors. The interaction between the cells and the substrate surface is critical where cell adhesion occurs by divalent cation and basic protein which occur between the solid surface and the cell membrane [7]. Under proper conditions, cells attach and spread onto the carriers and gradually grow out to a confluent monolayer [8].

Microcarrier culture comprises the cultivation of anchorage dependent cells on small solid substrate suspended in growth medium and thus can be cultured in larger scale. By using microcarriers in simple suspension culture systems, it is possible to achieve yields of several million cells per milliliter [9]. The microcarrier bioreactor culture system offers an attractive method for cell amplification and enhancement of phenotype expression. Besides serving as substrates for the propagation of anchorage-dependent cells, microcarriers can also be used to deliver the expanded undifferentiated or differentiated cells to the site of the defect [10]. Microcarrier culture also provides a method for rapid scaling-up with minimum number subculture steps [11]. However, cell differs in their attachment requirements, and thus a range of microcarriers should be assessed for suitability. There are various kinds of microcarriers based on material that were used.

\section{Experimental Details}

\subsection{Cell lines}

Vero cells (African green monkey kidney cells) were obtained from ATTC (CCL-81 $\left.{ }^{\mathrm{TM}}\right)$ Cells were kept cryopreserved in liquid nitrogen until further use.

\subsection{Culture Media and Chemicals}

RPMI (Cat.no 50-020-PB) and RPMI without phenol red 
(Cat.no 90-022-PB) were supplied by Cellgrow. Fetal Bovine Serum (FBS) (Cat. no 10270-098) obtained from Invitrogen and Accutase (Cat. no AT104) from Innovative Cell Technologies. Four different commercial microcarrier (MCs) were used which are Hillex ${ }^{\circledR}$ (Model no H112-170) and Plustic Plus (Model no PP102-1521) from Solohill (Michigan, USA); Cytodex 1 and Cytodex 3 from Amersham Biosciences (Uppsala, Sweeden). MCs were prepared for use as recommended by the manufacturers. All other chemicals were obtained from Sigma (St. Louis, USA).

\subsection{Preparation of Microcarrier (MCs)}

Cytodex 1, Cytodex 3, Hillex ${ }^{\circledR}$ and Plustic Plus microcarriers were prepared and sterilized according to manufacturer's instructions. For Cytodex 1 and Cytodex 3 with each $3 \mathrm{~g} / 1$, the microcarriers were swollen with $\mathrm{Ca}^{2+}$, $\mathrm{Mg}^{2+}$-free PBS twice and autoclaved at $115^{\circ} \mathrm{C}$ for 15 minutes while Hillex ${ }^{\circledR}(14 \mathrm{~g} / \mathrm{l})$ and Plustic Plus $(20 \mathrm{~g} / \mathrm{l})$ microcarrier were washed with deionized water and autoclaved at $121^{\circ} \mathrm{C}$ for 30 minutes. All microcarriers where incubated with the RPMI media before used.

\subsection{Cell Dissociation}

Media was discarded and cells were washed twice with phosphate buffer saline (PBS), $2 \mathrm{ml}$ Accutase enzyme were added to a $75 \mathrm{~cm}^{2}$ flask and cells were incubated for 2 minutes at $37^{\circ} \mathrm{C}$. Dislodged cells were then pooled with RPMI media contained 10\% serum and transferred into inoculums flasks.

\subsection{Spinner Flask Culture}

Cultures were carried out in $250 \mathrm{ml}$ spinner flasks (Bellco Biotechnology, U.S.A) containing $200 \mathrm{ml}$ of cultured cells, at $37^{\circ} \mathrm{C}$ in a $5 \% \mathrm{CO}_{2}$ incubator. The stirring speed was maintained at $30 \mathrm{rpm}$ at initial $\mathrm{pH}$ of the media adjusted to 7 . The spinners were inoculated with $2 \times$ $10^{5}$ cells $/ \mathrm{ml}$. The experiments were carried for 96 hours and sampling was done every 8 hours.

\subsection{Bioreactor Culture}

The cultures were performed in a two liters bioreactor (Labfors 3, Switzerland) containing one liter total working volume, equipped with a marine impeller. For starting the microcarrier cultures, RPMI media was mixed with $3 \mathrm{~g} / 1$ Cytodex 3 in the bioreactor and incubated for 3 hours with starting volume of $900 \mathrm{ml}$. Vero cells were detached from T-flasks using PBS and Accutase enzyme and $10 \%$ percent inoculums was added to the bioreactor culture. The culture was seeded with $2.5 \times 10^{5}$ cells $/ \mathrm{ml}$ and was continuously agitated at $70 \mathrm{rpm}$. During cell culture proliferation step, the following conditions were applied: $\mathrm{pH}$ set at 7.2; $\mathrm{pO}_{2}$ maintained at $30 \%$ air-satura- tion by injecting air or pure oxygen when required, temperature at $37^{\circ} \mathrm{C}$ and agitation rate at $70 \mathrm{rpm}$. The experiments were carried for 96 hours and sampling was done every 8 hours.

\subsection{Viable Cell Number (VCN) Counting}

Two milliliters of Vero cell culture were washed twice with PBS containing $0.02 \%(\mathrm{w} / \mathrm{v})$ EDTA at $\mathrm{pH} 7.6$. PBS was replaced with $0.25 \%(\mathrm{w} / \mathrm{v})$ trypsin in $\mathrm{Ca}^{2+}, \mathrm{Mg}^{2+}$-free PBS and EDTA $(0.02 \%, w / v)$ and the tube was incubated at $37^{\circ} \mathrm{C}$ for 15 minutes with occasional agitation. Two mililiter culture medium containing $5 \%$ serum was added to the microcarriers and centrifuged at $300 \mathrm{~g}$ and $4{ }^{\circ} \mathrm{C}$ for 5 minutes. The supernatant is discarded and the pellet is re-suspended in $2 \mathrm{ml} \mathrm{Ca}^{2+}, \mathrm{Mg}^{2+}$-free PBS containing $0.05 \%(\mathrm{w} / \mathrm{v})$ tryphan blue. The concentration of cells in the suspension is counted using haemocytometer.

\subsection{Calculation}

The specific growth rate $\mu\left(\mathrm{h}^{-1}\right)$ calculation was estimated by the following equation:

$$
\mu=\frac{\operatorname{In} X_{\mathrm{n}}-\ln X_{n-1}}{t_{n}-t_{n-1}}
$$

where $\mu$ (day $\left.{ }^{-1}\right)$ corresponds to the value of specific growth rate at any given time point, $t$ (hours) the culture time and $X$ (cells) the value of viable cell number for a specific $t$. The doubling time, $t_{d}$ (hour) calculation was estimated by the following equation:

$$
t_{d}=\operatorname{In} 2 / \mu
$$

\subsection{Monitoring Microcarrier}

Samples of Vero cells culture were examined microscopically using an inverted light microscope (Olympus, Japan). Five mililiters Vero culture was transferred into petri dish and was examined at three different microscopic fields per sample.

\subsection{Substrate Analysis}

Sample was centrifuged at $28,000 \mathrm{rpm}$ and $4^{\circ} \mathrm{C}$ for 15 minutes to remove cells and other contaminant. Supernatant was collected and filtered using 0.45 micron filter to remove any remaining particles. Glucose concentrations were monitored by High Performance Liquid Chromatography (HPLC) using SUPELCOGEL C-610H column equipped with a refractive index and $210 \mathrm{~nm}$ UV detector. Separation was done at $30^{\circ} \mathrm{C}$, eluted at 0.5 $\mathrm{ml} / \mathrm{min}$ using $0.1 \% \mathrm{H}_{3} \mathrm{PO}_{4}$ and each sample was analyzed for 30 minutes. 


\section{Results}

\subsection{Growth Kinetic of Vero Cells in Spinner Flask and Bioreactor Culture}

There were four runs in this experiment. Four types of different commercial microcarriers (MCs) were used as the substrate in this study which was Cytodex1, Cytodex3, Hillex ${ }^{\circledR}$ and Plastic Plus (PP). Figure 1 below showed growth profile of Vero cells in spinner flask on different MCs while Figure 2 determined percentage viability of the cells in the culture. The highest cell density was obtained at hour 88 and was equal to $2.4 \times$ $10^{5} \mathrm{cells} / \mathrm{ml}$ for $3 \mathrm{~g} / \mathrm{l}$ Cytodex 3. Cells showed an exponential growth for the period of 88 hour for Cytodex 3 and viable cells number decreased at hour 96. Cytodex 1 with the amount of $3 \mathrm{~g} / \mathrm{l}$ was still increased at the end of 96 hour period with absence of lag phase for both Cytodex 1 and Cytodex 3. Cytodex 1 reached the highest viable cell number of $1.5 \times 10^{5}$ cells $/ \mathrm{ml}$ followed by Hillex ${ }^{\circledR}$ which reached $1.35 \times 10^{5}$ cells $/ \mathrm{ml}$ and PP reached maximum cell number of $8.0 \times 10^{4}$ cells $/ \mathrm{ml}$, respectively. Vero-

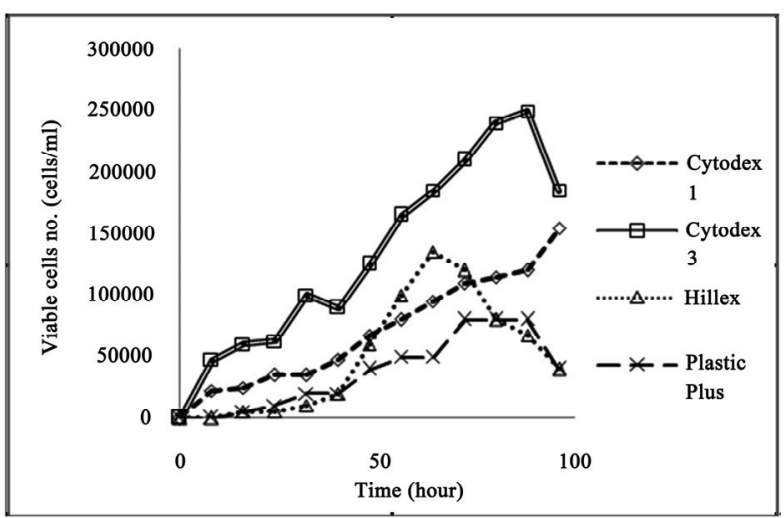

Figure 1. Comparison viable cell numbers of Vero cell harvested from four types of MCs in spinner flask for 96 hour period using RPMI growth medium supplemented with $10 \%$ FBS.

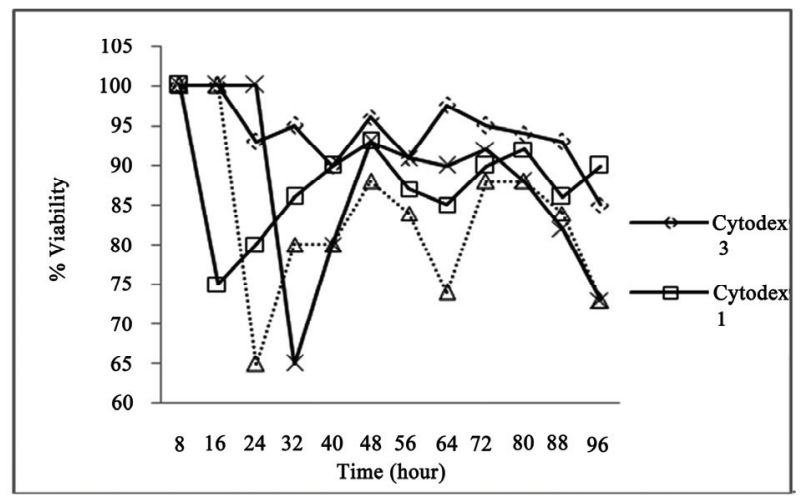

Figure 2. Percentage of cell viability in spinner vessel culture adhered slower to Plastic plus (PP) and Hillex ${ }^{\circledR}$ MCs with the existence of lag phase at initial 8 hours. Besides that, the cells was easily detached from these polystyrene core substrate (Hillex ${ }^{\circledR}$ and PP) after 80 hours in Hillex ${ }^{\circledR}$ MCs culture and reached stationary phase before dropped in cells number at 88 hour.

From Figure 2 above, percentage of viability of each MC was calculated. It was observed that average percentage of viability is $70 \pm 30$ for all MCs. Data for percentage viability for each MC was summarized in Table 1. Cells viability was highest in Cytodex 3 culture and lower in Hillex and PP culture. However, the range of viability indicated the viability is more that $50 \%$. Thus, this indicates the suitability of the condition parameter in spinner vessel for the cells to grow.

Calculation of specific growth rate and doubling time for four different MCs in spinner flasks was obtained using Equations (1) and (2). Average specific growth $(\mu)$ rate was determined at acceleration phase and Hillex ${ }^{\circledR}$ has the highest specific growth rate which is $0.087 \mathrm{~h}^{-1}$ and lowest doubling time; 7.97 hour followed by PP $(\mu=$ $0.046 \mathrm{~h}^{-1}, \mathrm{t}_{\mathrm{d}}=15.1$ hour $)$, Cytodex $3\left(\mu=0.022 \mathrm{~h}^{-1} ; \mathrm{t}_{\mathrm{d}}=\right.$ 31.5 hour $)$ and Cytodex $1\left(\mu=0.022 \mathrm{~h}^{-1} ; \mathrm{t}_{\mathrm{d}}=31.5\right.$ hour $)$. The results for Vero cells growth kinetic on each MC are summarized in Table 2. From the data, Cytodex 3 was used for scaling up Vero cell to two liters bioreactor and the performance of the bioreactor was compared to spinner vessel culture. Although Hillex ${ }^{\circledR}$ MC obtained the lowest doubling time which is 7.97 hour; it was not selected since the attachment of cells is slower and susceptible to cells detachment.

Cell started to grow immediately after bioreactor inoculation. The maximal cell density level in bioreactor was equal to $7.5 \times 10^{5} \mathrm{cells} / \mathrm{ml}$ and was reached at 72 hour after the start of the culture and the average specific growth rate increased and equal to $0.031 \mathrm{~h}^{-1}$ compared to

Table 1. Summarized percentage $(\%)$ cell viability in spinner vessel culture.

\begin{tabular}{crrcc}
\hline MCs & Cytodex 1 & Cytodex 3 & Hillex ${ }^{\circledR}$ & PP \\
\hline $\begin{array}{c}\text { Percentage } \\
\text { Viability }\end{array}$ & $85 \pm 8$ & $90 \pm 6$ & $77 \pm 15$ & $77 \pm 11$ \\
\hline
\end{tabular}

Table 2. Growth study of four different MCs in spinner flask.

\begin{tabular}{|c|c|c|c|c|}
\hline Responses & \multicolumn{2}{|c|}{ Cytodex 1 Cytodex 3} & Hillex ${ }^{\circledR}$ & $\begin{array}{c}\text { Plastic } \\
\text { Plus (PP) }\end{array}$ \\
\hline $\begin{array}{l}\text { Maximum Cell no } \\
(\text { cell } / \mathrm{ml})\end{array}$ & $\begin{array}{c}1.55 \times \\
10^{5}\end{array}$ & $\begin{array}{c}2.40 \times \\
10^{5}\end{array}$ & $\begin{array}{c}1.35 \times \\
10^{5}\end{array}$ & $\begin{array}{c}8.0 \times \\
10^{4}\end{array}$ \\
\hline $\begin{array}{c}\text { Avg. Specific } \\
\text { growth rate }(\mu), \\
h^{-1}\end{array}$ & 0.022 & 0.022 & 0.087 & 0.046 \\
\hline$\underset{\text { hour }}{\text { doubling time }\left(\mathrm{t}_{\mathrm{d}}\right),}$ & 31.5 & 31.5 & 7.97 & 15.1 \\
\hline
\end{tabular}


Cytodex 3 culture in spinner flask. Cells number was rapidly increased in the period of 48 hour and 56 hour where the number of viable cells was doubled. Figure 3 shows the absence of lag phase on both spinner vessel and bioreactor culture. However, the cells detached earlier in bioreactor culture at period of 72 hour while detached later in spinner vessel culture at 80 hour with the absence of the stationary phase. From Figure 4, doubling time of Vero cell was obtained as 22.4 hour compared to 31.5 hour in spinner vessel.

\subsection{Glucose Uptake in MCs Culture}

Regarding substrates glucose and metabolites profiles, glucose level consumed by the cells in MCs culture was observed during the cell growth phase and the results showed in Figure 5 and Figure 6. Glucose concentration was measured to infer the growth of cells in the MCs culture and the sample was analyzed for every 8 hours. Glucose concentration pattern was in decreasing order.

Figure 5 showed that glucose consumption was rapid in Cytodex 1 and Cytodex 3 in spinner vessel culture.

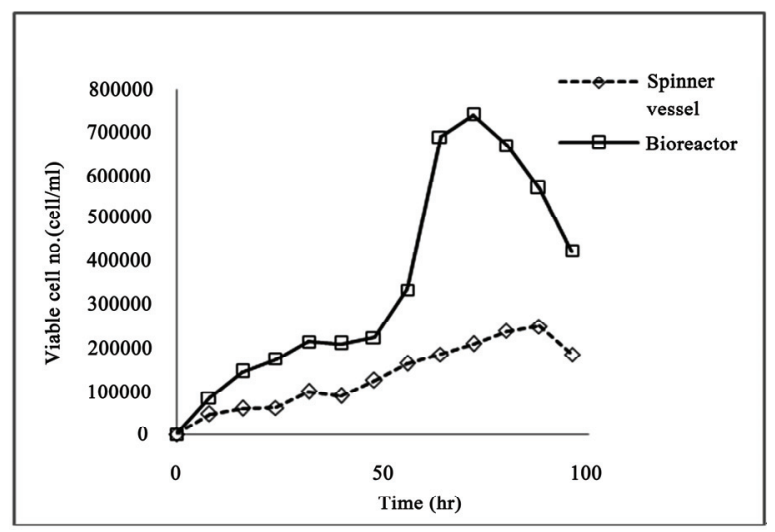

Figure 3. Growth profile of Vero cell culture in spinner flask and bioreactor using Cytodex 3 for period of 96 hours.

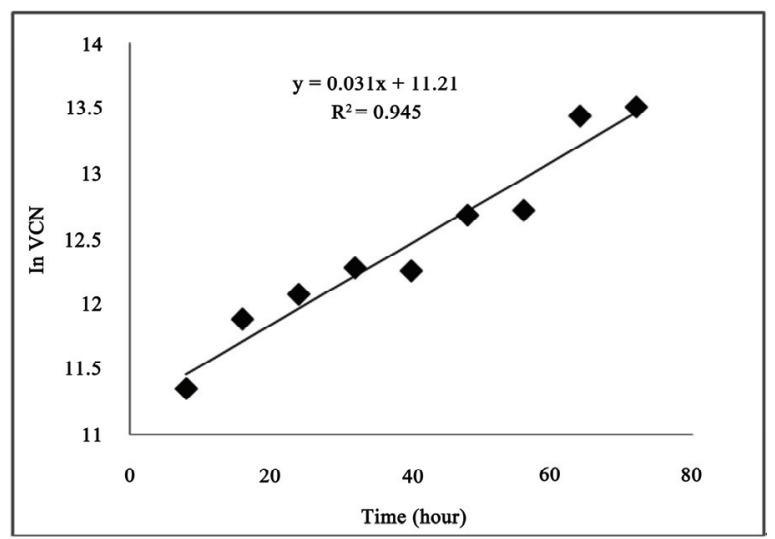

Figure 4. Specific growth rate of Cytodex 3 microcarrier obtained in bioreactor.

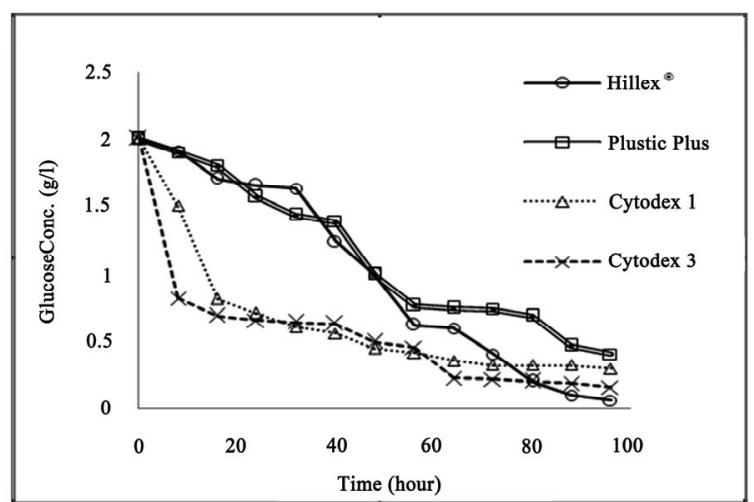

Figure 5. Glucose uptake by Vero cell in spinner flask culture.

Glucose uptake rate was higher for Cytodex 1 and Cytodex 3 for initial 8 hours and reduced gradually with time. However, glucose uptake was slower in Hillex and PP MCs culture and this explained the existence of lag phase period of these polystyrene MCs culture. Final glucose level of RPMI media was reduced to $0.517 \mathrm{~g} / 1$ in Cytodex 3 culture, $0.291 \mathrm{~g} / 1$ in Cytodex 1, $0.4 \mathrm{~g} / 1$ in PP and $0.061 \mathrm{~g} / 1$ in Hillex ${ }^{\circledR}$ culture with initial glucose level of 2 g/l. Figure 6 shows glucose uptake in bioreactor and spinner flask culture. Glucose uptake was slightly increased at initial culture which reached to $2.48 \mathrm{~g} / \mathrm{l}$ and rapidly decreases to final glucose concentration of $0.4 \mathrm{~g} / \mathrm{l}$. However, glucose concentration in spinner flask was reduced consistently with time from initial glucose concentration of $2 \mathrm{~g} / \mathrm{l}$ to $0.093 \mathrm{~g} / \mathrm{l}$. The glucose result shows that total consumption of glucose in bioreactor was reduced compared to spinner flask culture; but with better cells attachment.

\subsection{Cell Distributions and Morphologies on MC}

Observations under fluorescence microscope confirmed the existence of viable Vero cells on the surfaces of the microspheres.

Cell distribution on the microspheres shows in Figure 7 was observed after cultured for $80 \mathrm{~h}$ in spinner vessel. Cytodex 1 and Cytodex 3 MCs were fully covered by Vero cells where the cells were grown in multilayer and the cells distributed more densely on the Cytodex MCs, especially on the gelatin crossliked dextran (Cytodex 3). This is consistent with the cell proliferation and viability results in Figure 1. However, cells on PP MCs more difficult to be observed compared to other three MCs. Black region of Hillex ${ }^{\circledR}$ and PP MCs restricted cells visibility. In addition cells were bridge between these polystyrene core microspheres with elongated shapes. As a result, these MCs were bound together and were not easy to be separated. Moreover, only few separate cells were observed on PP MCs thus confirmed with the 


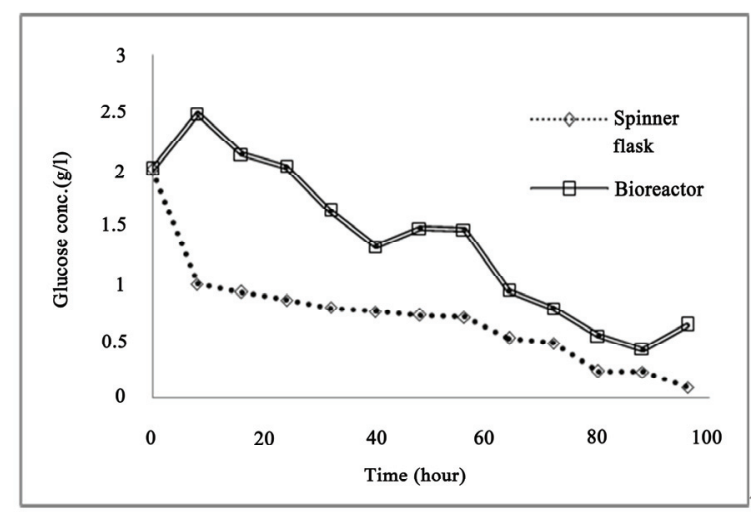

Figure 6. Glucose uptake of Vero cell using Cytodex 3 in bioreactor for period of 96 hours.

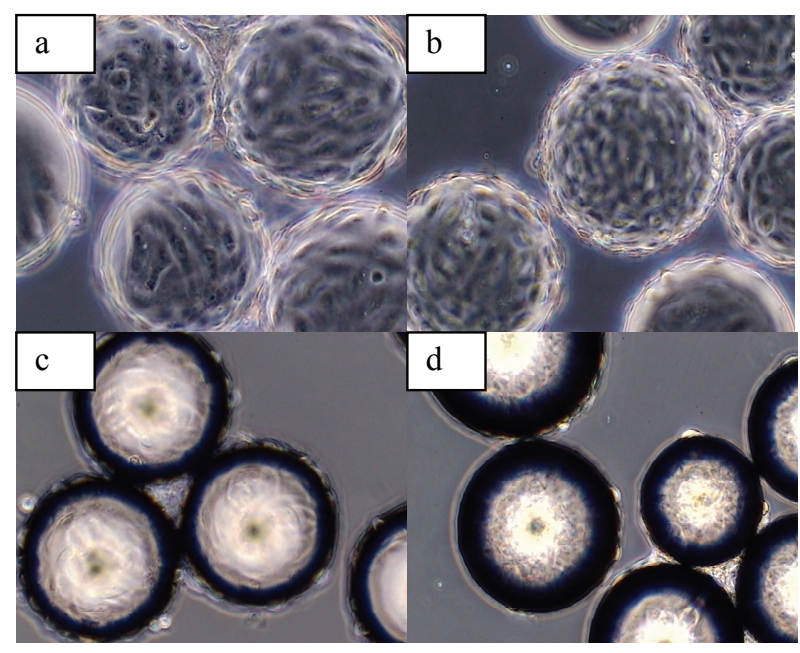

Figure 7. Cell Attachment of Vero cell on four different microcarriers in spinner flask after 80 hours viewed under electron scanning microscope at magnification of 20X; a) Cytodex 1; b) Cytodex 3; c) Hillex ${ }^{\circledR}$; d) Plastic Plus (PP).

growth profile of Vero in PP MCs. It was also observed that higher densities of cells on Cytodex 3 MCs in bioreactor compared to spinner vessel since higher maximum cell recovery was obtained.

\section{Discussions}

Results showed that the selection of the proper MCs is important to successful culture yield. In this study, cell growth was examined on four types of easily available MCs. The Vero cells adapted better to gelatin crosslinked dextran (Cytodex 3) in spinner flask suspension culture compared to other types of MCs. Cytodex 3 MCs yielded the highest viable cell number compare to other MCs (Figure 1) while PP and Hillex obtained lowest cell number with minimum cell recovery. This is because of the recovery of trypsin-released cells from the polystyrene MCs (Hillex ${ }^{\circledR}$ and PP) was more difficult and com- plicated [12], since lower density made sedimentation of MCs failed to adequately separate the cell polystyrene MC mixtures. Poor recovery of cells from the polystyrene MCs may partially account for the reduced cell counts reported here.

Furthermore, Cytodex 1 and Cytodex 3 have good microscopic ability compared to other MCs under study (Figure 7). Because of the opacity of the polystyrene MCs, the extent of cell attachment and growth was more difficult to determine microscopically. The advantage of Cytodex 1 and Cytodex 3 contributed easy monitoring cell growing behavior on MCs. Moreover, cells harvesting was easy for Cytodex 1 and Cytodex 3 since they readily degradable compared to polystyrene which is non-degradable [13]. Glucose data in Figure 5 analyzed consumption of glucose by the cells and it showed that glucose uptake was higher in Cytodex 3 culture compared to other types of MCs. It was also showed that glucose consumption was higher with higher adhered cell number since the cells consumed glucose and converted to energy that was used to attach on the surface of microcarriers as well as to support their live and growth [14]. Figure 6 however shows reduced glucose uptake in properly controlled bioreactor compared to spinner flask culture. Increase of glucose concentration at initial culture in bioreactor was expected due to serum containing glucose and thus subject to non-homogenous mixture during sampling.

Hillex ${ }^{\circledR}$ has highest specific growth rate which is $0.087 \mathrm{~h}^{-1}$ and lowest doubling time $(7.97 \mathrm{~h})$ compared to other MCs. However, they have lower maximum cell number than Cytodex MCs since adaption of the cells in this environment was slow. However, initial events that occur when cell adhere to surface is critical because adhesion precedes cell seeding and migration [15]. This fact explained for lower cells number obtained during the experiment. Furthermore, it was reported by Solo Hill Inc. [16] that Vero cells were not preferred to grow on plastic substrate. Results showed increasing viable cell number in bioreactor from Figure 3 compared to spinner flask culture. The results proved the suitability of Cytodex 3 for upscaling Vero cells from spinner flasks to bioreactor since critical parameters such as temperature, $\mathrm{pH}$ and $\mathrm{pO}_{2}$ was properly control in bioreactor. Thus, results show the compatibility of Vero cells for Cytodex MCs. Thus, results are consistent with other study where Cytodex ${ }^{\mathrm{TM}} \mathrm{MCs}$ was widely used for Vero cell culture in bioreactor. Furthermore, Cytodex 3 has been reported to have the advantages of can be reused $[17,18]$.

\section{Conclusions}

There are advantages and disadvantage relating to each MCs culture system which has to be evaluated depends 
on the purpose of the culture. In this study, Cytodex 3 in spinner flask give the best performance to be used with Vero cells culture compared to other types of MCs under study. MC achieved even higher cell concentrations in suspension of controlled bioreactors. Thus, Cytodex 3 believed to provide efficient system for production of larger scale high value products such as vaccine using Vero cells.

\section{Acknowledgements}

Thanks to laboratory assistant from Analytic Laboratory of Biotechnology Engineering of IIUM for his excellent work. This work was financially supported by the Ministry of Science and Technology (MOSTI) Malaysia.

\section{REFERENCES}

[1] R. Sheet, "History and Characterization of the Vero Cell Line, Technical Report," Vaccines and Related Biological Products Advisory Committee, 2000.

[2] K. Trabelsi, S. Rourou, H. Loukil, S. Majoul and H. Kalle, "Comparison of Various Culture Modes for the Production of Rabies Virus by Vero Cells Grown on Microcarriers in a 2L Bioreactor," Enzyme and Microbial Technology, Vol. 36, No. 4, 2005, pp. 514-519.

[3] S. Rourou, V. D. Ark, T. B. D. Velden and H. Kallel, "A Microcarrier Cell Culture Process for Propagating Rabies Virus in Vero Cells Grown in a Stirred Bioreactor under Fully Animal Component Free Conditions," Vaccine, Vol. 25, No. 19, 2007, pp. 3879-3889.

[4] O. Kistner, M. K. Howard, M. Spruth, W. Wodal, P. Bruhl, M. Gerencer, A. Brian, H. D. Crowe, I. Livey, M. Reiter, I. Mayerhofer, C. Tauer, L. Grillberger, W. Mundt, F. G. Falkner and N. P. Barrett, "Cell Culture (Vero) Derived Whole Virus (H5N1) Vaccine Based on Wild-Type Virus Strain Induces Cross-Protective Immune Responses," Vaccine, Vol. 25, No. 32, 2007, pp. 6028-6036.

[5] H. Huang, X. Yi and Y. Zhang, "Improvement of Vero Cell Growth in Glutamate-Based Culture by Supplementing Ammoniagenic Compounds," Process Biochemistry, Vol. 41, No. 12, 2006, pp. 2386-2392.
[6] F. Horaud, "Absence of Viral Sequences in the WHO Vero Cell Bank: A Collaborative Study," Development of Biological Standardization, Vol. 76, 1992, pp. 43-46.

[7] M. Butler, "The Basics Animal Cell Culture and Technology," Oxford University Press, Oxford, 1996.

[8] C. A. M. Groot, "Microcarrier Technology, Present Status and Perspective," Cytotechnology, Vol. 18, No. 1-2, 1995, pp. 51-56.

[9] H. Clark, K. Dai and K. Masashi, "The Design of Polymer Microcarrier Surfaces for Enhanced Cell Growth," Biomaterials, Vol. 24, No. 23, 1999, pp. 4253-4264.

[10] J. Malda and C. G. Frondoza, "Microcarriers in the Engineering of Cartilage and Bone," Trends in Biotechnology, Vol. 24, No. 7, 2006, pp. 299-304.

[11] A. J. Sinskey, R. J. Fleischaker and M. A. Tyo, "Production of Cell Derived Products: Virus and Interferon," Annals of the New York Academy of Sciences, Vol. 369, No. 1, 1981, pp. 47-64.

[12] L. A. White and E. W. Ades, "Growth of Vero E-6 Cells on Microcarriers in a Cell Bioreactor," Journal of Clinical Microbiology, Vol. 28, No. 2, 1990, pp. 283-286.

[13] B. L Seal, T. C. Otero and A. Panitch, "Polymeric Biomaterials for Tissue and Organ Regenaration," Materials Science and Engineering, Vol. 34, No. 4, 2001, pp. 147 230.

[14] R. Freshney, "Culture of animal cells," Wiley and Sons, Hoboken, 1998.

[15] M. Saltzman and Kyriakides, "Principle of Tissue Engineering," Elsevier Inc, Houston, 2007.

[16] Solo Hill Engineering Inc, "Solohill Microcarrier Beads," 2009. http://www.solohill.com/files/microcarrier_beads.pdf

[17] S. C. Wu, C. C. Liu and W. C. Lianc, "Optimization of Microcarrier Cell Culture Process for the Inactivated Enterovirus Type 71 Vaccine Development," Vaccine, Vol. 22, No. 29-30, 2004, pp. 3858-3864.

[18] Y. Wang and F. Ouyang, "Recycle of Cytodex-3 in Vero Cell Culture," Bioprocess Engineering, Vol. 21, No. 3, 1999, pp. 207-210. 